\title{
SEEING THE WHOLE BY SPOTTING A PART
}

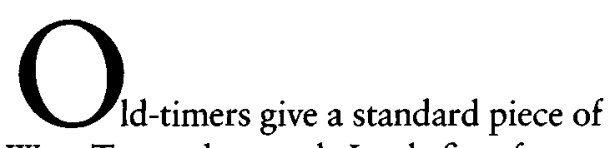
advice on spotting deer in the West Texas chaparral. Look first for an ear or a leg. Light, shadows, and brush trick the eyes into missing the whole, but they seldom hide every part. Historians too understand that a bewildering array of contradictory details, incomplete evidence, or thick layers of interpretation, like light, shadows, and brush, trick observers of the past. They seek out an appropriate part to illuminate the whole. Such is the purpose of this political, economic, social, and cultural history of Northeast Texas, a region that offers much to carry forward in looking at all of Texas and the South.

Based on the experiences of Northeast Texans, historians have underestimated the level, type, and consequence of change between 1887 and 1930. State boundaries influenced this change as the region and almost certainly the rest of Texas diverged from the pattern of neighboring southern states. Significant change did not simply await the external forces let loose by the New Deal and World War II. Instead, a more competitive political arena, an economy with more opportunities and incentives for innovation and growth, and a more fluid society and culture allowed Texans to initiate change before 1930 . Those changes and the conditions that produced them prepared Texans to take better advantage of the opportunities presented by the New Deal and World War II. Yet southern characteristics, developed over the previous century, remained obvious. ${ }^{1}$

From the I820 until near the close of the nineteenth century, Texas, and especially Northeast Texas, grew steadily more like such classic southern states as Tennessee, North Carolina, Georgia, Alabama, and Mississippi. The chance for economic advancement - the viability of slavery and plantation agriculture-drew a steady stream of southerners to 


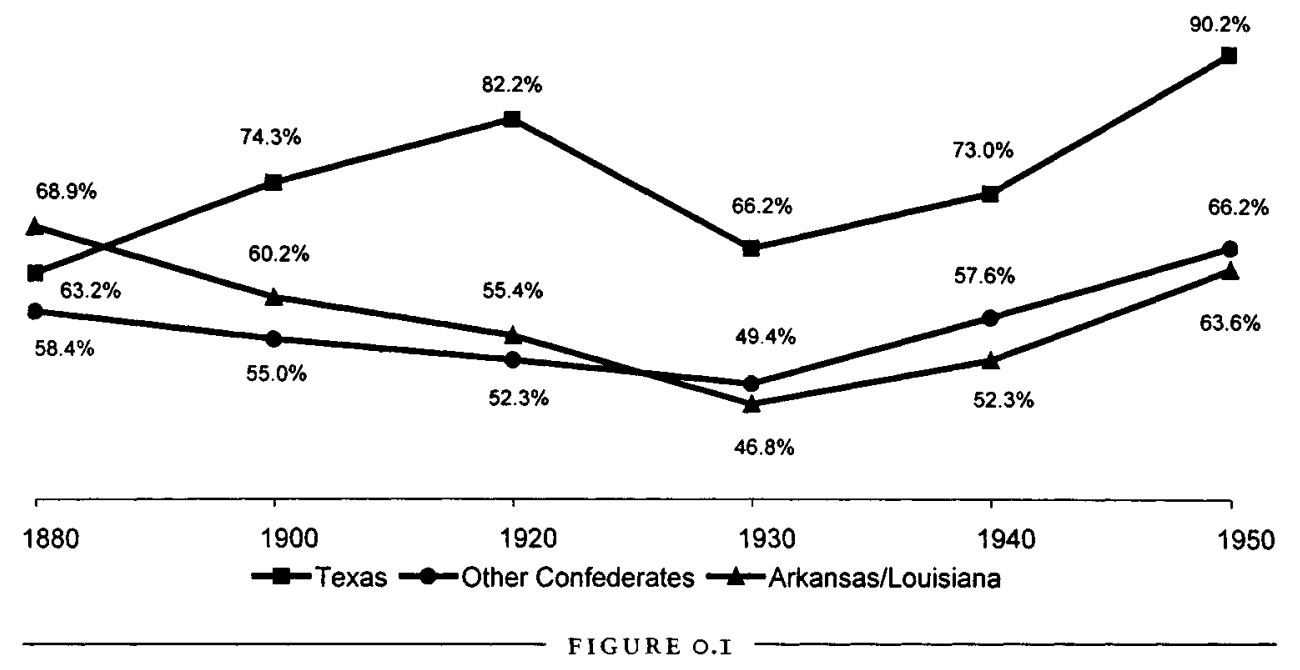

Changes in per capita income, $1880-1950$

(as a percentage of U.S. per capita income).

Source: Maurice Levin, Income in the Various States, Its Sources and Distribution, 1919, 1920, 1921 (New York: National Bureau of Economic Research, 1925); Charles F.

Schwartz and Robert E. Graham, Jr., Personal Income by States since 1929, supplement to

Survey of Current Business (Washington: Department of Commerce, 1956); Richard

Easterlin, "Interregional Differences in Per Capita Income, Population, and Total Income, I840-1950," in National Bureau of Economic Research, Trends in the American Economy in the Nineteenth Century (Princeton: Princeton University Press, 1960).

antebellum Texas. As the prospects for cotton improved, new Texans came increasingly from the Lower South states. In I86I Texas joined the original Confederacy of these Lower South states. Significantly, Texas seceded before Arkansas, North Carolina, Tennessee, and Virginia, suggesting it was far from being a border state. The Civil War experience drew Texans even more tightly into the southern orbit. Texans shared the memory of defeat and the reality of postwar poverty. Less intensively developed, however, Texas continued to draw southerners, white and black, to its productive and relatively inexpensive soil. By the early I89os Confederate mythology, a cotton-based economy, a common culture based on evangelical Protestantism, racial violence, and ties of friendship and kinship linked Texans more firmly then ever to the South. Texans' key role in the development of southern Populism demonstrated the oneness of Texas and the rest of the South. ${ }^{2}$

Still, divergence between Texas and the rest of the South began in the midst of the Populist furor, as suggested by Figure 0.1. ${ }^{3}$ Before I90I, meaning before substantial economic growth in West Texas and before 
the discovery of significant amounts of oil in the state, Texans' per capita income diverged from that of the ten other Confederate states. Even more interestingly, it diverged from its neighbors Arkansas and Louisiana. The dip in 1930, however, suggested that Texans' income remained tied to cotton prices, as did income in other southern states. ${ }^{4}$

After 1930, economic development in Texas moved the state rapidly toward convergence with the rest of the United States, but numbers tell only part of this ambiguous story. Bruce Schulman, in his study of the impact of federal policy on the South after 1938, observed that during World War II, "Texas leaders exploited their state's advantages in ways that North Carolina's did not." Texans, led by Jesse H. Jones and other key members of government, obtained more than their share of federal benefits during the New Deal and World War II. Texas farmers, for example, received substantially more benefits per capita from 1933 to 1939 than did farmers in any other southern state. ${ }^{5}$ Yet Texans' avid pursuit of those benefits, regardless of how it might upset their traditional society, truly marked them as different from most other southerners. Nothing demonstrated this difference in attitudes and aspirations more profoundly than the key role that Texan Lyndon Johnson played in the Civil Rights Movement. By the I930s, when Johnson first began his rise to prominence, Texans' past had better prepared them to maximize new opportunities and put aside old prejudices. ${ }^{6}$

Statistical similarity and other similarities with the South before 1887 and greater dissimilarity after 1930 suggest that the years in between hold the key to the emergence of modern Texas. Here lies one part of the whole - answers to why Texas began changing and what prepared Texans to pursue even greater change. Here lies the beginning point of examining how the rest of the South did and did not resemble Texas. Yet too many conflicting details, too few complete sets of evidence, and a confining historiography make writing coherently about the whole of Texas in these years exceptionally difficult.

Geographers call Texas a transitional area and avidly analyze the five or more distinct zones of vegetation, soil, and terrain. The presence of distinctive and long-lasting German, Czech, and Mexican folk islands added to the variety of the cultural landscape. A long border with another country, Mexico, further complicated the Texas past. Still, blacks and whites from the South composed the largest population groups until recent times, and nothing in the climate or terrain of the eastern two-thirds of the state slowed the spread of southern-style agriculture. Even the western third of the state, despite its arid climate, long displayed many southern characteristics, especially regarding religion and race. ${ }^{7}$ Yet explaining 
what was southern and not southern offers such a challenge that some historians of the South have simply ignored Texas, leaving its history for the indiscriminate use of historians of the West. ${ }^{8}$

While the diversity of Texas and its unique location cause mental overload, the paucity of published works on anything but politics in the postReconstruction period presents another series of problems. Few secondary sources exist on which to build a broad-gauged study of Texas, and such a book would require mining primary sources from each of the state's many regions. ${ }^{9}$

In part this lack of work on areas besides politics comes from historians' preconceptions. Much of the literature on the South and Texas treats the period from 1887 to 1930 as politically discrete but as economically and socially an extension of the late nineteenth century. Populism, Progressivism, and the legal development of Jim Crow get much attention. Economic growth, when noted, seems minimal and within preexisting parameters. While some historians acknowledge social and cultural change, many view it as a frozen era. As Edward L. Ayers puts it in The Promise of the New South, "The same processes worked throughout the region after 1906 as before." Saying over and over that nothing changed, that the same basic processes continued until the New Deal, keeps us from looking for evidence to the contrary. ${ }^{10}$

Such preconceptions require testing, and the diversity of Texas together with the lack of work on anything but politics argue for a test done in a tightly focused area with the greatest possible similarity to the rest of the South. Among the diverse regions that made up Texas, none were more like the rest of the South than the First Congressional District in the state's northeast corner. South and west of the Red River lay Bowie, Camp, Cass, Delta, Franklin, Hopkins, Lamar, Marion, Morris, Red River, and Titus counties, the focal points of this study. ${ }^{11}$ Like most rivers, the Red united as much as it divided the people in its valley, and Northeast Texans shared much with their neighbors in Oklahoma, Arkansas, and Louisiana. This makes the area an ideal spot for close examination, a place to expand analysis of Texas and the South. ${ }^{12}$

A quick survey of the land and people in the eleven counties shows just how representative they were of the Red River area and of the South in I887. The eastern counties-Bowie, Camp, Cass, Marion, and Morrismirrored neighboring counties and parishes in Arkansas and Louisiana. Pine forests and acidic, sandy soil predominated in the uplands but gave way to rich, easily cultivated alluvial soil and extensive stands of oak, hickory, walnut, and cypress along the Red and Sulphur rivers and their smaller tributaries. Farmers and merchants could reach the head of navi- 


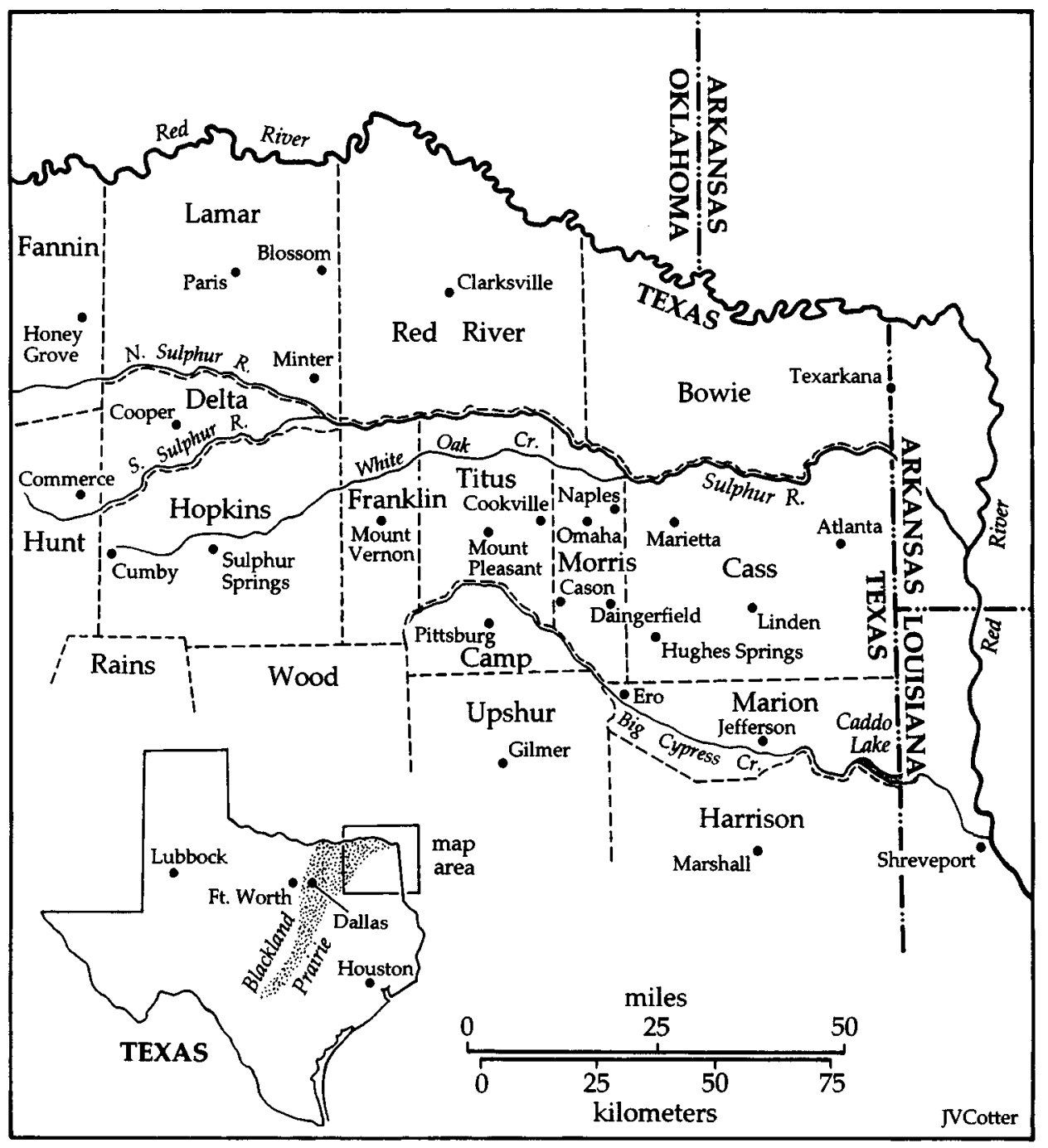

F IGURE 0.2

Northeast Texas. Map by Jobn V. Cotter.

gation on the Red River, and this allowed the development of antebellum slavery and cotton plantations. Large-scale cotton plantations, often utilizing black tenants, continued to dominate the economy after the Civil War as the area filled up with transplanted southerners. In the I88os, the lumber and railroad industries increased in importance and brought lim- 
ited manufacturing to the eastern counties, but cotton long dominated the local economy. ${ }^{13}$

Not surprisingly, blacks made up a large percentage of the total population. In 1890 blacks in Marion and Camp counties constituted more than half the population. Despite a slight decline in the percentage of blacks in their total population, as late as I930 Bowie, Camp, Cass, Marion, and Morris counties combined had about the same percentage black as Louisiana, roughly 37 percent. $^{14}$

The western counties resembled their neighbors in Southeast Oklahoma and North Texas. As you moved westward in Red River and Titus counties, gently rolling prairies with scattered islands of post oaks gradually replaced swampy river bottoms and forested uplands. Pines virtually disappeared. Present, however, were the same rich soils near the rivers and creeks and the easily cultivated sandy soils away from the rivers. In Lamar, Delta, Hopkins, and Franklin counties, plentiful rain fell on prairie soils, and native grasses dominated the landscape into the twentieth century. Post oak mottes and the densely wooded margins along rivers and creeks gave variety to the landscape. Clarksville, in Red River County, served as an early center of trade and commerce, but limited transportation slowed the full development of the antebellum plantation system in the western counties. Even so, the rich calcareous "black waxy" prairies, sandy loam gray lands, and alluvial bottomlands attracted a surprising number of prewar settlers. ${ }^{15}$

As transportation improved after the war, cotton replaced hay, corn, and small grains in the western counties. By 1890 the productivity of the soil made the area a mecca for southern farmers and firmly established it as a center of the cotton industry. Financing and insuring cotton, producing cottonseed oil, and manufacturing gins and other equipment needed in the cotton trade made the region more than just a land of farms. ${ }^{16}$

Despite the boom in cotton, blacks never numbered more than a third of the population of any western county. In I890 Red River County's blacks made up about $3^{\mathrm{I}}$ percent of the population, while in Delta they made up only 8 percent. As in other areas in or near the Texas Blackland Prairie, converting more acreage into cotton production attracted many more whites than blacks. ${ }^{17}$ By 1930 blacks in Lamar and Red River formed only about 22 percent of the population, similar to the percentage in $\mathrm{Ar}$ kansas. In Franklin, Delta, and Hopkins counties, the percentage black dropped to near 7 percent, about the same as in Oklahoma. Titus fell in between with about I5 percent black. ${ }^{18}$

As Table 0.I shows, the district grew substantially whiter after I880. Yet, the percentage black for the district in 1930 remained greater than the 
T A B LE O.I

First District Population by Race

\begin{tabular}{lrrrrrr}
\hline $\begin{array}{l}\text { District } \\
\text { Population }\end{array}$ & \multicolumn{1}{c}{ I880 } & \multicolumn{1}{c}{ I890 } & \multicolumn{1}{c}{ I900 } & \multicolumn{1}{c}{ I9I0 } & I920 & \multicolumn{1}{c}{ I930 } \\
\hline Total & 126,339 & 170,001 & 220,322 & 239,341 & 271,472 & 255,552 \\
White & 85,671 & 118,769 & 159,071 & 174,192 & 204,215 & 190,451 \\
$\quad \%$ total & 67.8 & 69.9 & 72.2 & 72.8 & 75.2 & 74.5 \\
$\quad \%$ change & & 38.6 & 33.9 & 9.5 & 17.2 & -6.7 \\
Black & 40,555 & 51,149 & 61,231 & 65,143 & 67,251 & 64,505 \\
\% total & 32.1 & 30.1 & 27.8 & 27.2 & 24.8 & 25.2 \\
\% change & & 26.1 & 19.7 & 6.4 & 3.2 & -4.1 \\
\hline
\end{tabular}

Source: U.S., Census: 1880-1930, Population.

percentage black in Texas or in Oklahoma, Arkansas, Texas, and Louisiana combined. ${ }^{19}$

Other demographic characteristics of the region also echoed those of the cotton-growing South. Northeast Texas lacked the large urban centers that powered the economic development of Texas as a whole but by 1890 boasted two flourishing small cities. ${ }^{20}$ Paris, in Lamar County, and Texarkana, in Bowie County, served trade areas that crossed state and county boundaries and had many more manufacturing plants than other towns in the district. This helped Paris reach a population of about 8,000 and Texarkana about 6,000 (Arkansas and Texas) in I890. Texarkana's factories milled lumber and manufactured furniture and other wood products. Railroad machine shops added metal-working capacity to the industrial mix. The city's boundary crossed over into Arkansas, and roughly 45 percent of its citizens lived in that state. This border status made Texarkana an attractive place for the regional headquarters of several railroad and timber companies. In Paris, flour milling, cottonseed processing, and the production of food products combined with banking, wholesale distribution, and the cotton trade to create a healthy urban economy. As in Texarkana, several railroads met in Paris, making it a leading shipping point. Yet in 1930, the population of Texarkana, by then the larger of the two, still numbered fewer than $30,000 . .^{21}$

Their commercial and industrial base gave Paris and Texarkana a slightly different demographic profile from the rest of the region. Nevertheless, in Bowie County, from 1890 to 1930 fewer than 2 percent of the population fit the census category foreign-born white, and that together with the absence of Lutherans and the small number of Catholics sig- 


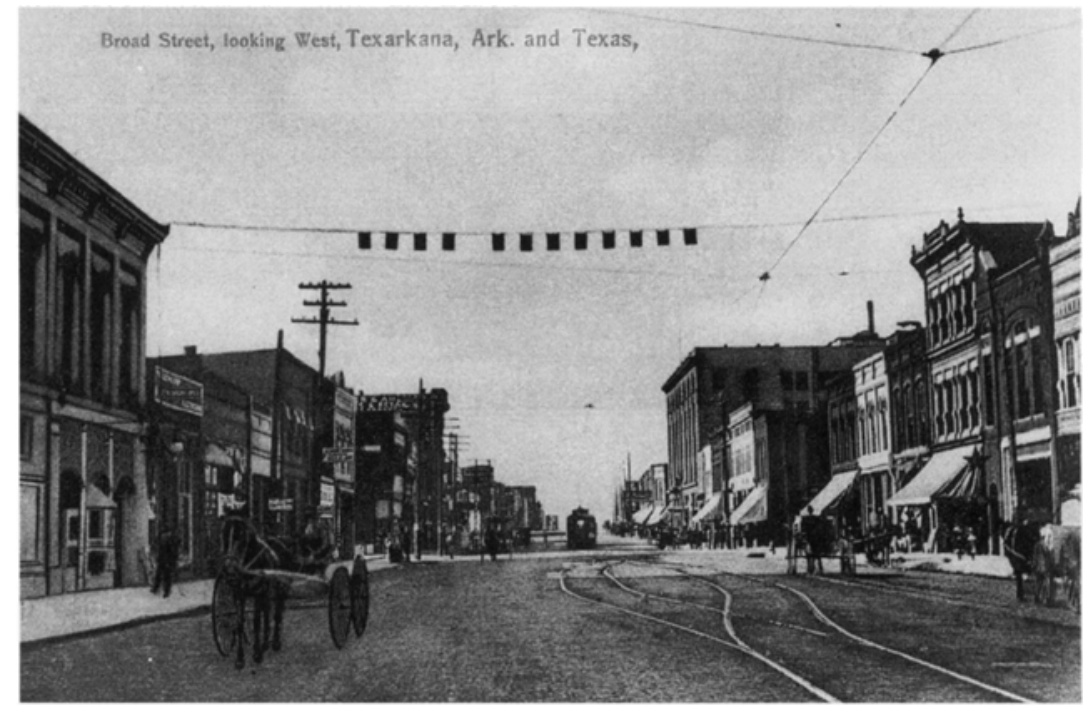

F I G URE 0.3

Broad Street in Texarkana in about 1900 . Texarkana grew rapidly after 1890 as railroads and lumber companies consolidated their operations within its boundaries.

Located astride the border between Arkansas and Texas, the city soon boasted such modern amenities as electric streetcars.

Photograph courtesy of Jenkins Garrett Texas Postcard Collection, University of Texas at Arlington, Special Collections.

naled that few German, Czech, Cajun, and Mexican Texans lived there year round. Even Bowie, the most ethnically diverse county in the region, fell within typical southern demographic parameters. ${ }^{22}$

Clearly, the Red River did not divide the geography and society of adjacent areas of Texas, Oklahoma, Arkansas, and Louisiana. Nor did the Red totally divide the economy. As in the rest of the South, tenancy increased after 1890 and erratic cotton prices dogged farmers, but the citizens of the Red River Valley suffered fewer economic calamities than southerners to the east. In the I920s the valley escaped the alternating ravages of a flooded Mississippi River and severe droughts. Greater productivity partially insulated some farmers from boll weevil damage and wild swings in cotton prices. Larger towns flourished. Better economic conditions on the plains of West Texas and in nearby cities like Dallas and Fort Worth offered a way out..$^{23}$ The relative economic health of the region, the nearness of significant opportunities to get ahead, and the presence of islands 
of prosperity separated the valley from what Jack Temple Kirby called "retrograde cotton counties of the South." ${ }^{24}$

In Northeast Texas, in particular, more than luck and location separated residents from the most devastated areas of the South. The region, so much like the rest of the South in 1887 , arrived at a different end point in 1930 because business trends, law, public policy, aspirations all shaped by politics and culture-gave the region a bit more prosperity. Being Texan offered subtle economic advantages that eluded other southerners and that allowed higher incomes and different reactions to federal policy. Just as the focus of this study narrows to one time period and one region of Texas, it narrows repeatedly to one underlying questiona question that opens the way to answers to many others. In Northeast Texas did being part of Texas matter?

Answers about the importance of state boundaries traditionally fall in three categories: politics, economics, and culture. V. O. Key posited that Texas's particular racial characteristics made its politics slightly different from the politics of the rest of the South. The concentration of blacks in a minority of Texas counties offered the promise of moving beyond the use of race to gain office and allowed the existence of two competing factions within the Democratic party. While often acting in typical southern fashion, Texans stood the best chance of varying from the norm. Conversely, Gavin Wright argued that eastern Texas had the same closed labor market as the rest of the South and that this limited the economy. For him, and for most economic historians, state boundaries meant far less than the boundaries of a traditional cotton-growing culture. Yet many have argued that another type of culture set the state apart. After observing the state, John Steinbeck wrote that Texas "is a mystique closely approximating a region" and "its unity lies in the mind." Myth made Texas. Northeast Texans' experiences between 1887 and 1930 challenge and qualify all three standard interpretations. ${ }^{25}$

Not two, but three or more roughly equal political factions existed throughout the period from 1887 to 1930 . This phenomenon prevented one faction from ever gaining the upper hand without compromise and conciliation and limited conservatives' influence. Among the other southern states, Texas as a whole perhaps most resembled North Carolina. Certainly that comparison struck Schulman when he examined the behavior of their politicians in the I930s and I940s. During an earlier time, a coalition of Populists and Republicans controlled North Carolina's government. In the mid-I89os this coalition had more real political power than Texas Populists ever achieved. Using race baiting, fraud, intimida- 
tion, and appeals to the Confederate past, North Carolina conservatives soon regained control, and they remained in control into the post-World War II period. In contrast to North Carolina, from I 887 to 1930 conservatives never consistently controlled politics in Northeast Texas or in the state at large. ${ }^{26}$

This dynamic political landscape allowed legal changes that aided the growth of an economy that began to accelerate in the mid-I890s, and economic growth soon joined the distinctive political structure in providing a foundation for change. Instead of being an isolated backwater, Northeast Texas was connected to, and affected by, the even more dynamic centers of economic change in Texas and, through them, to others elsewhere in the United States. These new centers of prosperity offered markets for alternatives to cotton, magnets for surplus labor, and dissemination points for the latest business methods. Nothing in the political system hampered this process. All of this led to a restructured economy and society by the late I920s. Of course, elements of this restructuring, particularly the increase in the number of sharecroppers, magnified the painful impact of the Great Depression and New Deal policy. The patterns of growth that emerged by 1930, however, also sped recovery. Northeast Texans found themselves better able to do something about what Gilbert Fite called "the unfavorable balance between land and people" that mired southern agricultural areas in poverty. ${ }^{27}$

Culture eventually joined politics and economics in creating an environment that allowed innovation and change, but Steinbeck and others mistakenly assumed that Texans always considered themselves exceptional. Instead, until about I9Io Northeast Texans thought and acted more southern than Texan. Like citizens of the rest of the former Confederate states, they built monuments to the Lost Cause and fervently worshiped the memory of Confederate heroes. Between I9ro and the early I920s that tendency reversed as Northeast Texans became more Texan than southern. Over the course of the I920s an attachment to local history and folk culture further obscured a sense of being southern. As these transformations progressed, Texans more freely acted as Americans instead of southerners. Northeast Texans, in particular, increasingly accepted middle-class movements that took women outside the home and family and relied more on the state and federal governments. They optimistically reached for an American future, instead of rigidly defending a Confederate past. ${ }^{28}$

In Northeast Texas, cultural fluidity, economic growth and innovation, and a more open political system operated interactively. Each factor not only influenced the others, the region changed because of its connections 
to the rest of the state. While Key missed the trifactional nature of Texas politics, he accurately insisted on the importance of the relationship of the parts of a southern state to the political whole. Multifactionalism, for example, benefited from the strength of ethnic communities and from the rapid growth of several large cities with a diverse economy in other parts of Texas. This distinguished Northeast Texas from Georgia, where intense factionalism also made state politics a bit more open and competitive than the norm..$^{29}$

In like fashion, connections between the parts of the state and connections between economics, politics, and culture explained why Texans better exploited the advantages offered by the federal government in the I930s and I940s. Gavin Wright pointed out that southern politicians did not use their power to bring federal largess to their region for fear of pushing up regional wages. Yet Wright Patman, who for forty-seven years served the First District in the House of Representatives, consistently led the fight to push up the minimum wage and to expand the availability of credit for the common man. In this fight he took advantage of a tightly knit Texas congressional delegation, a group determined to bring industry and capital to Texas. ${ }^{30}$

From 1928 on, Patman enjoyed unusual popularity in his district, never facing a runoff election. To a large extent, the region's political, economic, and cultural history explained Patman's success. As Key noted and North Carolina demonstrated, the faction representing the less prosperous proved the most unstable, but in Northeast Texas it survived to combine with factions in the middle of the ideological spectrum and elect Patman and others like him. Continuity of leadership and a more institutionalized structure made the less prosperous a reliable voting bloc. Likewise an economy that brought greater competition to small-town shopkeepers gave them incentive to support a congressman who championed anti-chain-store legislation. Finally Patman fit the culture of his time and place. He never used Confederate rhetoric and avoided race baiting in politics. Instead he projected an active pioneer image that stressed a Texan's ability to get the job done. ${ }^{31}$

Differences in race relations in their home districts did not fully explain Patman's and other Texans' variation from a more typical southern pattern. Certainly the gruesome history of lynching in Northeast Texas testified that race counted as much there as anywhere else in the South. After 1887 the pace of lynching quickened in the region and matched the barbarity of anything found in Georgia or Mississippi. Intense local criticism of lynching in the early I920s, however, drastically reduced the practice. Lynching became un-American, an unacceptable cultural trait 
with the added liability of being bad for business. Like slavery, postwar poverty, and other southern characteristics, Texans soon wrote lynching out of their state's history and achieved "reconciliation of progress and tradition" by remembering a nonsouthern past. ${ }^{32}$

What mattered though was not simply that Northeast Texans changed their history, but that they enjoyed an extended period without a fixed history. As late as 1920, devotion to Texas history remained embryonic, still moving toward the point where, as one Northeast Texan declared: "In my native state patriotism flourished as does the prickly pear: evergreen and everywhere, however poor the soil, and just as thorny. The cactus may be made edible for the Texas cattle by singeing it with a flamethrower, but not even one of those things could smooth a Texan when, rubbed the wrong way, his patriotism bristles." ${ }^{33}$ Like the multifactional political system and the more dynamic economy, a less fixed sense of the past fostered acceptance of new ideas and new attitudes. Whereas other southern states boasted "few supports for innovation," being in transition from the old Confederate myth to the new Texas myth allowed greater flexibility and acceptance of innovation. That as much as anything explained why Texas diverged from the rest of the South after 1930.34

By 1930 being modern meant achieving material prosperity through more efficient use of new technology and new methods of business organization. Modernity required a readiness to embrace the federal government's help in remaking the region. Modern Texans rejected the most violent forms of racism, abandoned the innovation-numbing Confederate culture, and accepted an expanded role for women. Being modern meant not just having changed, but readying for further change.

As the chapters that follow outline, these transformations rose from the foundation of a more open political system and a changing economy. They developed within the context of the move from a multiparty to a one-party system and sprang from the interconnection between politics, law, and culture. An erratic economy after r9r4 and the broad impact of World War I induced further change. In the r920s, demographic trends underscored the need to accept modernity, while the political system, despite the impact of the Ku Klux Klan, continued to favor moderate candidates backed by a broad coalition. During the late r 920 , operating within this distinctive political system and reacting to a new culture, Northeast Texans abandoned most aspects of their traditional society. Some may argue that at that point the region and the state ceased to be southern. For good reasons Northeast Texans would never have agreed. 